\title{
Érico Veríssimo, a Brazilian Cultural Ambassador in the United States
}

\author{
Richard Cándida Smith[1]
}

\begin{abstract}
This article examines the goals that the U.S. government had in inviting the writer Érico Veríssimo for successive trips from 1941 on, when it got in touch with editors, reviewers and the audience. It also analyses the effects of developing long-lasting connections with the United States on his career; explores the factors that contributed to Veríssimo's success in the United States; and examines the difficulties he faced when negotiating with North American publishers; finally, details Veríssimo's role as a public speaker in the United States promoting greater public understanding of Brazil while, most importantly from the U.S. government perspective, building support within the United States for the Good Neighbor Policy and U.S. military installations inside Brazil.
\end{abstract}

Keywords: Érico Veríssimo, Good Neighbor Policy, book publishing.

\section{Érico Veríssimo, um embaixador cultural nos Estados Unidos}

Este artigo examina os objetivos do governo dos EUA em convidar o escritor Érico Veríssimo para sucessivas viagens a partir de 1941 quando travou contato com editores, crítica e público. Analisa ainda as consequências que sua longa permanência nos EUA teve sobre sua carreira; explora os fatores que contribuíram para o sucesso de Veríssimo nos EUA, ao mesmo tempo em que examina as dificuldades que enfrentou na negociação com os editores norte-americanos; finalmente, avalia o papel assumido por Veríssimo, em suas conferências públicas, como o promotor de um maior entendimento sobre o Brasil no marco da política da Boa Vizinhança e a construção de instalações militares no interior do Brasil.

Palavras-chave: Érico Veríssimo, Política da Boa Vizinhança, publicações.

\section{Érico Veríssimo, embajador cultural en Estados Unidos}

Ese artículo examina los objetivos del gobierno de EUA en convidar al escritor Érico Veríssimo para diversos viajes desde el 1941 cuándo el tubo contacto con editores, críticos y público. Esto analisa también las consecuencias en su trayectoria profesional de sus largas permanencias en EUA; bucea los factores que contribuyeron para el éxito de Veríssimo en EUA, al mismo tiempo que examina las dificultades que el escritor enfrentó en la negociación con los editores estadounidenses; finalmente, evalúa el rol asumido por Veríssimo, en sus conferencias públicas, como el promotor de un entendimiento más amplio sobre el Brasil, en el marco de la política de la Buena Vecindad y del crecente interese estratégico de EUA en el Brasil.

Palabras clave: Érico Veríssimo, Política de la Buena Vecindad, publicaciones.

\section{Erico Verissimo: un ambassadeur culturel aux États-Unis}

Cet article examine les objectifs du gouvernement américain d'inviter Érico Verissimo pour voyages successifs depuis 1941, quand il a contacté editeurs, les critiques et le public. Nous analysons egalement les conséquences de cette long séjour dans son travail. Ce travail explore egalement les facteurs qui ont contribué à la réussite de l'auteur aux États-Unis, ainsi que les dificultés qu'il a rencontré pour né- gocier avec les éditeurs américains. Enfin, nous évaluons le rôle assumé par lauteur, dans ses confé- rences publiques, comme un promoteur une meilleure compréhension du Brésil et de la politique de bon voisinage, ainsi que l'intérêt stratégique croissant des États-Unis sur le Brésil. Mots-clés: Érico Veríssimo; Politique de bon voisinage; publications. 
I n 1937, German intervention in the Spanish Civil War and Japan's invasion of China signaled that a second world war was imminent. The leading figures in Franklin Delano Roosevelt's administration understood that the United States would be drawn into the war and could play a decisive role in its outcome. Public opinion, however, remained adamantly opposed to involvement, and Congress responded to the international threat by cutting military spending and passing legislation barring the U.S. government and private citizens from assisting any belligerent. In July 1938, in order to combat isolationist sentiments, the State Department created a Division of Cultural Relations. While much has been written on the functions of this division in shaping public opinion in other countries to support U.S. policy goals, the primary purposes of new cultural exchange programs were internal, to change domestic public opinion. ${ }^{1}$ Richard Pattee, ${ }^{2}$ the deputy chief of the new division charged with pan-American exchange, stressed that

Not only must channels be opened for the free flow of our ideas and cultural production to other countries, but, just as important, channels must also be opened for the flow of cultural production from other countries to the United States. Intellectual co-operation would be a vain and meaningless

\footnotetext{
'On the history of U.S. government cultural exchange programs, see Richard T. Arndt, The First Resort of Kings: American Cultural Diplomacy in the Twentieth Century, Washington, Potomac Books, 2005; Frank A. Ninkovich, The Diplomacy of Ideas: U.S. Foreign Policy and Cultural Relations, 1938-1950, Cambridge, Cambridge University Press, 1981; J. Manuel Espinosa, Inter-American Beginnings of U.S. Cultural Diplomacy, 1936-1948, Washington, Bureau of Educational and Cultural Affairs, Department of State, 1976. a semi-official history written by a staff member of the Division of Cultural Affairs; Ruth Emily McMurray and Muna Lee, The Cultural Approach: Another Way in International Relations, Chapel Hill. University of North Carolina Press, 1947, a comparison of U.S. cultural exchange efforts with those of several other major world powers written by veterans of the U.S. program. State Department programs built on principles of exchange moving in both directions have been overshadowed in the historical literature by discussion of the Office of Inter-American Affairs, launched by Franklin Delano Roosevelt within the White House, under the direction of Nelson Rockefeller. OIAA cultural programs focused on projecting U.S. positions into Latin America, but also included sending U.S. writers, artists, filmmakers, and photographers to Latin America to develop work for U.S. audiences about their allies in the Pan American Union. OIAA activities included commercial programs, as well as overseeing contractors constructing military bases, launching public health programs, and in general assuring that U.S. strategic goals in Latin America remained on track. See Richard T. Arndt, "Welles, MacLeish, and Fulbright as Architect-Exemplars of Early Postwar Cultural Diplomacy," online at http://streitcouncil.org/uploads/PDF/As\%2OArchitect-Exemplars\%20-\%2OArndt.pdf, and Arndt, The First Resort of Kings, p. 75-97. Gisela Cramer and Ursula Prutsch, "Nelson A. Rockefeller's Office of Inter-American Affairs (1940-1946) and Record Group 229," Hispanic American Historical Review, vol. 86, 2006, p. 785-806.

${ }^{2}$ Pattee, born in Arizona in 1906, studied at the University of Arizona and the Catholic University of America. He worked on colonial-era Ecuador, but also wrote on Haiti and Brazil. His writing often focused on the role of the Catholic Church in Latin America, largely assessing its contributions to social development in positive terms through a focus on movements within the church to assert its independence from crown domination during the colonial period and then after independence by acting as a check on the arbitrary power national leaders had seized. His work also included an interest, unusual for the time, in African American culture throughout the western hemisphere. His publications show that, in addition to his determination to defend the Catholic Church as a source of stable progress, he was a follower of Cuban anthropologist Fernando Ortiz and was influenced by Ortiz's conception of "transculturation," in which American cultures can be seen as emerging over time through a process of initially diasporic cultures converging. His books include Jean-Jacques Dessalines, fundador de Haití, Havana, Molina, 1936; Gabriel García Moreno e a sua contribuição científica no Equador, Lisbon, Sociedade Industrial de Tipografia, 1937; García Moreno y la política internacional ecuatoriana, Quito, Romero, 1939; The Catholic Revival in Mexico, New York, The Paulist Press, 1944, Introducción a la civilización hispanoamericana, Boston. Heath, 1945; El catolicismo contemporáneo en Hispanoamérica. Buenos Aires, Editorial Fides, 1951; Haití, pueblo afroantillano, Madrid, Ediciones Cultura Hispánica, 1956. He was an assistant professor of history at the University of Puerto Rico before 1938, when he joined the Division of Cultural Affairs. He resigned from the State Department in 1945 to become a professor of history at the Catholic University of America.
} 
term if only a unilateral policy were carried out. [...] the Division of Cultural Relations will contribute in no small way to the spread of a knowledge of foreign cultures among our own people. ${ }^{3}$

Pattee prepared the new division's work plan for cultural exchange with Latin America. In a memo written in January 1939, Pattee argued that the single most important objective was to bring Latin American intellectuals to the United States and help them develop long-term personal friendships and institutional connections. ${ }^{4}$ State Department assistance should focus on introducing Latin American authors into the U.S. national book and magazine markets, and, when possible, into Hollywood. Bringing Latin American literature and journalism to the attention of the U.S. public was essential, given that most of the histories of the region available in English focused on government leaders and formal constitutional arrangements without consideration of everyday lived experience. Stereotypes of every kind prevailed, and would continue to do so as long as readers in the United States had no way of comparing what U.S. writers produced about Latin America with what their counterparts in other American nations were doing. U.S. writers on Latin America too often highlighted the "spectacular and the grotesque" to such an extent that most countries appeared to be "little else than a chamber of horrors." Understanding the opinions of Latin Americans, Pattee declared, was more important to the United States, as it developed a new relationship with the region, than publishing yet more suppositions from North American writers about "what Latin America is." The new program looked for contemporary Latin American authors who might be of interest to U.S. readers. ${ }^{5}$

In late 1940, Érico Veríssimo, author of six novels, one collection of short stories, and 17 children's books, unexpectedly received an invitation from the

\footnotetext{
3Richard Pattee, "The Role of the Teacher of Spanish in the Promotion of Inter-American Cultural Relations," Hispania, vol. 22, 1939, p. 236.

4Pattee's memo in the papers of the US Department of State, Record Group (RG) 59, Decimal File for 1930-1939, 841.43/30, National Archives, Washington; reproduced in full in J. Manuel Espinosa, Inter-American Beginnings of U.S. Cultural Diplomacy, Washington, D.C., Bureau of Educational and Cultural Affairs, U.S. Department of State, 1976, p. 167-169. See also Helen R. Pinkney, "The Division of Cultural Cooperation," unpublished TS, December 1945, in RG 59, War History Branch Studies, box 10: CU file.

${ }^{5}$ See also Richard Pattee, "Review," Journal of Negro History, vol. 23, 1938, p. 383. State Department programs built on principles of exchange moving in both directions have been overshadowed in the historical literature by discussion of the Office of Inter-American Affairs, launched by Franklin Delano Roosevelt within the White House, under the direction of Nelson Rockefeller. The OIAA focused on projecting U.S. positions into Latin America. Its activities were more broadly based, with the charge of coordinating cultural and commercial programs, but also overseeing contractors constructing military bases, launching public health programs, and in general assuring that U.S. strategic goals in Latin America were on track. See Richard T. Arndt, "Welles, MacLeish, and Fulbright as Architect-Exemplars of Early Postwar Cultural Diplomacy," online at http://streitcouncil.org/uploads/PDF/As\%2OArchitect-Exemplars\%2O-\%20Arndt. pdf, and Arndt, The First Resort of Kings, p. 75-97. For official statements of Division of Cultural Relations objectives see Ben M. Cherrington, "The Division of Cultural Relations," Public Opinion Quarterly, vol. 3, 1939, p. 136-138; Cherrington, "Cultural Ties That Bind in the Relations of the American Nations," Hispania, vol. 22, 1939, p. 243-250; Cherrington, "Editorial: Education and Cultural Relations," The Phi Delta Kappan, vol. 22. November, 1939, p. 75-76. On the OIAA, see Cary Reich, The Life of Nelson A. Rockefeller: Worlds to Conquer, 1942-45, New York, Doubleday, 1996.
} 
U.S. State Department to tour the United States - all expenses paid. ${ }^{6}$ At 35 years old, he was one of Brazil's most popular younger writers, but none of his work had yet been translated into English. From January to April 1941, he traveled across the United States, meeting politicians, celebrities, business leaders, and a sprinkling of average citizens. During his odyssey, he gave 24 lectures on Brazilian literature and society to both civic groups and university classes. His book reporting his impressions, Gato Preto em Campo de Neve, remains in print, and is a classic in the field of travel literature. As an effort to influence public opinion in Brazil, the U.S. State Department considered its invitation to Veríssimo to have been exceptionally successful. Gato Preto em Campo de Neve was a "best-seller" of its kind, with a sale of 15,000 copies in the first two months, a sales figure that, at the time, was said to have exceeded any previous book published in the country. ${ }^{7}$

The book presented a largely positive account of a people Veríssimo described as fundamentally peaceful and inward looking but grappling with many questions, foremost among them in 1941, whether the United States would to go to war against Hitler. The book generated extensive discussion within Brazil, generally in a positive tone. The questions of war and peace that the United States faced also pressed on Brazil, divided over its responsibilities in world affairs, unsure whether aligning with the United States against Germany would lead to U.S. culture flooding into the country and overwhelming everything distinctive about Brazilian society. ${ }^{8}$ Veríssimo reminded his readers that Americans and Brazilians knew little of each other. Americans confused Brazil with Spanish-speaking America and often assumed that it was a primitive place where most people walked around without clothes. He noted that, when he visited the Philadelphia Academy of Natural Sciences, his host "mostra-me gráficos e instrumentos com ar um pouco protetor como se estivesse revelando a um selvagem recém-chegado à civilização as maravilhas produzidas pelo cérebro privilegiado do homem branco. Fica entre surpreendido e incrédulo quando lhe digo que no Brasil conhecemos a luz elétrica, o microscópio e a máquina fotográfica." 9 Brazilians, for their part, typically imagined that the United States was a place filled with gangsters, cowboys, and "fallen women."

In either direction, formulas and prejudices substituted for real knowledge, but Veríssimo assumed that reliance on stereotypes reflected lack of knowledge rather than prejudice. Veríssimo continually insists throughout the book that the United States was filled with marvels that were possible

\footnotetext{
6Daniel M. Braddock, U.S. Consul, Porto Alegre, to Érico Veríssimo, 29 November, 1940, Acervo do EV, IMS Veríssimo was the first Brazilian recipient of a "Leader Grant" from the U.S. State Department. Among the several hundred Brazilians brought to the United States between 1941 and 1945 were anthropologist Gilberto Freyre, historian Sérgio Buarque de Holanda, historian and novelist Vianna Moog, journalist and novelist Orígenes Lessa. Worldwide, the State Department offered approximately 1,000 grants a year between 1940 and 1948, money used to fund visits and/or extended stays to the United States (Richard T. Arndt. The First Resort of Kings: American Cultural Diplomacy in the Twentieth Century, Washington, Potomac Books, 2005, p. 137. Veríssimo described the circumstances of the invitation in his memoirs, Solo de clarineta: Memórias, vol. 1. Porto Alegre: Editora Globo, 1973, p. 276-277.

${ }^{7}$ Sales figures cited in L. L. Barrett, review of an edited version of Gato preto em campo de neve prepared for Portuguese students in the United States, Hispania, vol. 32, 1949, p. 265. Veríssimo's papers at the Instituto Moreira Salles suggest that initial sales of Gato preto in 1941 may well have been as high as 20,000 copies. ${ }^{8}$ On the question of growing U.S. influence within Brazilian society, see Antonio Pedro Tota, O Imperialismo Sedutor: A Americanização do Brasil na Epoca da Segunda Guerra, São Paulo: Companhia das Letras, 2000. 'Érico Veríssimo, Gato Preto em Campo de Neve, São Paulo: Companhia das Letras, 2006, p. 130.
} 
to achieve only when a people "sente a beleza" and "é capaz de poesia." ${ }^{10}$ This, Veríssimo argued, reflected an attitude towards life similar to that of most Brazilians, who much like Americans were generous and open hearted, but also largely ignorant of the world outside their immediate lives. The two countries, which Veríssimo assumed were to become allies, were both like adolescents excitedly searching for the poetry of existence gave him hope for the world's future. For peace to be restored, for there to be an end to dictators, for a new world where good will, poetry, fantasy, diversity, and tolerance flourished, Americans and Brazilians needed to know each other on a deeper level than they ever had in the past, even though neither people was particularly sophisticated or worldly. The bureaucratic formulas of the "Good Neighbor Policy" were largely silly, he added, but, to the degree that the United States government pursued people-to-people contact, its actions encouraged hope. ${ }^{11}$

The United States had long been a place Veríssimo wanted to see firsthand, in part because of the many Hollywood movies he had seen since his childhood, in part because of the many short stories and novels by U.S. authors he had translated into Portuguese. ${ }^{12}$ As a writer also working as an acquisitions editor for a Brazilian publisher, he was particularly interes-

The two countries, which Veríssimo assumed were
to become allies, were both like adolescents excitedly
searching for the poetry of existence gave him hope
for the world's future

ted in how U.S. publishing houses selected the books they released. During his stay in New York City, the State Department arranged for him to meet with editors of some of the biggest companies in the country. At Macmillan, Veríssimo learned that "de certo modo, guardadas as proporções, os nossos problemas são os mesmos com que lutam os editores norte-americanos". ${ }^{13}$ Macmillan had discovered Margaret Mitchell and published her first novel, Gone with the Wind, a worldwide success that sold millions of copies. No Brazilian publisher could ever hope for sales even a small fraction of that figure, but Theodore Purdy at Macmillan assured him that very few books sold more than 100,000 copies. A successful book sold between 10,000 and 50,000 copies, each generating a small profit for the firm. Macmillan stayed in business by publishing a large list, most of which sold reasonably well,

\footnotetext{
${ }^{10}$ Érico Veríssimo, Gato Preto em Campo de Neve, São Paulo: Companhia das Letras, 2006, p. 161. "IIbidem, p. 130-133, p. 473-477.

${ }^{12 E}$ Érico Veríssimo, Solo de clarineta: Memórias, Tomo 1, Porto Alegre: Globo, 1973, p. 113. He also attended a high school in Porto Alegre, Brazil, run by Americans. While a student there, he developed his fluency in English. ${ }^{13}$ Érico Veríssimo, op. cit., p. 206.
} 
with a handful generating extremely large profits. ${ }^{14}$ The "avalanche" of paper included many mediocre books, but the process also allowed editors room to publish books simply because they admired the quality of the author's writing. Veríssimo, who worked for Editora Globo, a small press that eventually transformed into one of the most important mass-media companies in the world, pondered the tension between quality and commerce that had become typical of U.S. culture:

A casa editora que quiser ter recursos materiais suficientes para se aventurar ao lançamento de livros de autores, como, por exemplo, Thomas Mann [...] terá de ir buscar esses recursos na publicação [...] duma Agatha Christie. Não se pode exigir que a massa ame Marcel Proust e deteste Margaret Mitchell. Por outro lado, absurdo será também pensar que o gosto do público não seja passível de evolução [...] Na minha opinião, o artista que se entrega passivamente ao povo, fazendo-lhe todas as vontades no afã de ser-lhe sempre agradável, corre um risco de destruição irremediável; mas o que despreza esse mesmo público fica sujeito a se tornar inumano, precioso e isolado da vida e das suas verdades simples. ${ }^{15}$

The cultural system that the United States produced gave Veríssimo hope as an author that he could conceivably reach the U.S. public, and the people he had met struck him as curious and eager to learn. At the same time, the U.S. publishing business was in a position to fulfill one of the basic conditions for Americans to know more about Brazil and its people. U.S. publishers were able to take financial risks, and the men and women he spoke to seemed genuinely interested in publishing Brazilian authors. Veríssimo personally agreed with one of the basic propositions behind the State Department's efforts at cultural exchange: when books from Latin America started appearing in the United States, when they found readers and generated informed criticism, the Good Neighbor Policy would move to a new stage. Instead of being an alliance of convenience that suited the needs of the Roosevelt and Vargas administrations, Veríssimo believed that the people in both countries would start getting involved. They themselves would demand more contact. Stereotypes would linger, as, Veríssimo noted, the human mind seemed to need ready-to-hand formulas for looking at what was outside immediate personal experience, but, if contact increased, formulas would come into conflict with experience. The publics in both countries would demand more information as they began to learn more of the reality of the other country.

\section{Becoming a best-selling author}

Veríssimo came from a "traditional" land-owning family based in Cruz Alta, Rio Grande do Sul. His father, who in addition to owning land ran

\footnotetext{
${ }^{14}$ The firm also got half of its business from the production and sales of text-books. Macmillan was the pioneer in the U.S. book-publishing business of establishing regional warehouses, which allowed the firm to supply a larger volume of inventory across the country than its competitors. On the history of Macmillan, see John Tebbel, A History of Book Publishing in the United States, vol. 3, The Golden Age Between Two Wars, 19201940, New York, Bowker, 1978, p. 101-103, p. 535-537; John Tebbel, A History of Book Publishing in the United States, vol. 4, The Great Change, 1940-1980, New York, Bowker, 1981, p. 118-130.

${ }^{15}$ Érico Veríssimo, Gato Preto em Campo de Neve, São Paulo: Companhia das Letras, 2006, p. 364
} 
a pharmacy, went bankrupt in 1922 and lost everything. Veríssimo, studying at a private high school run by Episcopalians from the United States, had to leave school a year before he was to graduate and go to work. His mother left her husband to return to her parents, also "traditional" land owners who had lost most of their wealth when they could not pay off mortgages taken out to develop their land. She supported herself and her two sons by running a small dressmaking business out of her parents' home, while Veríssimo worked, first in an uncle's warehouse, then in a bank. When he turned twenty, a relative bought a pharmacy that Veríssimo ran for three years. He augmented his income by teaching English, and he began doing his first translations from English and French. ${ }^{16}$

In 1930, he moved from his hometown of Cruz Alta to Porto Alegre, where, after publishing his first short story, the editors of a local magazine, the Revista do Globo, offered him a job. Veríssimo's primary responsibility was to scour newspapers and magazines from the United States, Britain, Germany, France, Italy, and Argentina to locate stories and articles that might interest the readers of the Revista do Globo and then translate them into Portuguese. Operating on a shoestring, the journal had no money for buying rights, and the editors simply pirated foreign content they wanted to publish. ${ }^{17}$

The job quickly educated Veríssimo in the standards of commercial literature published in Europe and North America. In the process, he developed a Portuguese-language style that effectively communicated the sentiments of global middle-class literature to Brazilian readers. As his employer expanded into publishing books, also typically pirated, Veríssimo translated U.S. and English detective novels as well as more serious fiction by a wide variety of prominent authors, including Aldous Huxley, John Steinbeck, W. Somerset Maugham, and Katherine Mansfield. His employer put him in charge of the program to publish translations of classic and contemporary literature, with re-publication of U.S. books, the highest priority for Veríssimo's employers. Veríssimo selected titles to be translated and supervised the translators he hired. In this capacity, Veríssimo introduced many North American writers to the Brazilian reading public for the first time. ${ }^{18} \mathrm{He}$ began publishing his own short stories in the Revista do Globo, and Clarissa, his first novel appeared in 1933 - a book Veríssimo later noted was modeled after the work of Katherine Mansfield and Francis Jammes, two authors whose novels

\footnotetext{
16“Memória seletiva: O tempo e os ventos," Cadernos de Literatura Brasileira: Érico Veríssimo, vol. 16, 2003, p. 8-10. ${ }^{17}$ The state of Rio Grande do Sul had laws protecting publishers who pirated materials from other countries, or even other parts of Brazil. The principle behind the laws was that providing as much information as possible to the people had higher value than protecting intellectual property rights. With the onset of the Great Depression, foreign books became prohibitively expensive, and imports stopped. Publishing foreign titles in pirated translations allowed Brazilian readers to remain in contact with literary developments in other countries. See Laurence Hallewell, Books in Brazil: A History of the Publishing Trade, Metuchen, New Jersey, Scarecrow Press, 1982, p. 228-232.

${ }^{18}$ Érico Veríssimo, Solo de clarineta: Memórias, Tomo 1, Porto Alegre: Globo, 1973, p. 233-252; “Guia Érico Veríssimo: O Arquipélago," Cadernos de literatura brasileira, vol. 16, 2003, p. 164-165; Felipe José Lindoso, "A indústria editorial no Brasil no século XX," in Historia de las empresas editoriales de América Latina, siglo XX, ed. Juan Gustavo Cobo Borda, Bogotá, Centro Regional para el Fomento del Libro en América Latina y el Caribe, 2000, p. 122-124; Laurence Hallewell, op. cit., p. 227-242.
} 
he had published in Portuguese translation. ${ }^{19}$ Given everything he had to do, his own writing happened "in between everything else," ${ }^{20}$ but, in 1938, his fifth novel, Olhai os lírios do campo, turned without any expectation into Brazil's first bestseller, selling some 40,000 copies. He was one of three Brazilian writers at the end of the 1930s whose income as an author, while modest by standards in Europe and the United States, could conceivably support him and his family. He continued as foreign book editor and translator for Editora Globo, while he continued to write a new novel every year. ${ }^{21}$

Around the time of his first visit to the United States, Veríssimo jotted down a note in English about himself and his goals as a writer: ${ }^{22}$

It is very difficult to be a professional writer. If you want to make a living from your writing you must publish at least one book per year. But you cannot do that without endangering the very quality of your books. Take my case, for instance. I mean my novels. I am able to turn out a novel each year. I am sure they may be very readable novels. ${ }^{23}$

Two years later, in a letter sent to a studio official at Warner Brothers, Veríssimo observed:

I am now starting a new novel. I hate to write a book each year, but I can't help it. Writing is my 'racket.' And moreover I don't believe in masterpieces. We are living in a mad and changing world. It is no use to polish and repolish what you write in order to cause the book to last. What is going to last of the thousands and thousands of books that are being published in these days of our years? ${ }^{24}$

Veríssimo was trying to interest producers in one of his books, and the letter accompanied a manuscript of Olhai os lírios do campo in English translation.

Unlike most other writers of his generation, his formation, particularly his being thrown into the initial development of mass media in his own country, made him particularly well prepared to speak to the U.S. reading public; few other writers of his generation in Latin America had so thoroughly internalized the demands of modern consumer culture. Nonetheless, despite the apparent interest of many editors in his work and a commitment from the State Department to provide subsidies to help a publisher pay for the additional costs of translation, the path to publication in the United States proved difficult. The middle and late 1930s had been very good years for the book business, and competition to find the next potential best-seller intensified.

\footnotetext{
19Érico Veríssimo, Solo de clarineta: Memórias, Tomo 1, Porto Alegre: Globo, 1973, p. 253. 20/bidem, p. 254

${ }^{21}$ In 1942, Veríssimo wrote a fellow Brazilian author whose book he had convinced Editora Globo to republish, “De 1938 para cá minhas relações com a livraria são quasi exclusivamente as de editores e editado. Tenho ainda um escritório no 'estabelecimento,' onde sou encontrado diariamente. E só tenho a ver diretamente com a escolha da obras estrangeiras. Fora disso, entrego-me a meus próprios livros" (EV to Oswald de Andrade, 3 agosto 1942, Acervo do EV, IMS).

${ }^{22}$ When Veríssimo began planning a new book, his initial notes were typically written in English ("Manuscritos/ Inéditos," Cadernos de literatura brasileira, vol. 16, 2003, p. 75.

${ }^{23}$ Untitled, undated notes, Acervo do EV, IMS. In the 1930s, Veríssimo produced at least one book a year. In the 1940s, he began to spend more time on the books he wrote. The note states he had written six novels, which would date it between 1940 and 1943.

${ }^{24}$ Érico Veríssimo to John Leroy Johnston, 14 May 1942, Acervo do EV, IMS
} 
The business model, however, remained uncertain since sales varied dramatically. In 1936, for example, to take two of the most famous books published in the United States that year: Margaret Mitchell's Gone with the Wind sold 1.7 million copies while William Faulkner's Absalom, Absalom sold 6,000 ones. Mitchell's book was the only title that sold more than 100,000 copies that year, and it would not be until 1941 that another book broke the 100,000 sales mark. Publishers did not require or expect large sales on every title, but operated on the assumption that the larger number of released titles increased the possibilities for success as long as most titles generated a steady if modest income. Publishers relied on the over 15,000 public libraries to provide a minimum number of sales. Purchasers for libraries were not concerned with whether they personally liked a given book or not; they needed to serve a range of tastes within their given communities by providing readers with books that had gained attention in major newspapers and national magazines, while avoiding books that could be considered offensive to community values. Reviews in the general press and in specialized library journals provided libraries with the information they needed to know which books to buy. ${ }^{25}$

Publishers needed new manuscripts to maintain a volume of production that had proved overall profitable, but the number of submissions increased at a much faster rate than the increase in titles accepted. Any publisher's review process had to weed out the large majority of potential books hopeful authors or their agents sent in. Manuscripts were judged quickly, and the assumption was that a book would be rejected unless it leapt out and seized the imaginations of reviewers. In Veríssimo's case, there was additional confusion over how to assess what would make a Brazilian writer appealing to U.S. readers. Translations of classic novels by Machado de Assis and Aluísio Azevedo had previously appeared in English. A small press had published a translation of Mário de Andrade's Amar, verbo intransitivo in 1933, but in general, contemporary Brazilian fiction had no track record in the broader U.S. book market. The experts on Latin America that publishers turned to for advice provided negative reports of Veríssimo's work. He heard from a writer friend he knew in New York that Ernesto Montenegro, a Chilean journalist living in the United States, had become the reviewer of Latin American books for Farrar and Rinehart, arguably the most important publisher of foreign literature in the United States at the time. Montenegro dismissed Veríssimo's novels as written for Latin ladies who like to weep, rather than for readers looking for serious literature. Veríssimo, Montenegro concluded, needed to learn more about the tastes of the U.S. reading public. ${ }^{26}$ Greenberg Publisher, another press that the State Department was trying to interest in Latin

\footnotetext{
${ }^{25}$ Wayne A. Wiegand, "The American Public Library: Construction of a Community Reading Institution," in A History of the Book in America, vol. 4, Print in Motion, p. 431-451. See also John Tebbel, A History of Book Publishing in the United States, vol. 3, The Golden Age between Two Wars. New York: Bowker, 1978, p. 657-690. Statistics for titles and copies produced are available, but publishing firms were reluctant to release firm information about sales.

${ }^{26}$ Angèle Kathleen Gingras to Érico Veríssimo, 10 February 1941, Acervo do EV, IMS. Veríssimo thought Montenegro was wrong in his evaluation of the U.S. book market. Numerous best-sellers, among them Rebecca, Gone with the Wind, and How Green Was My Valley proved that many U.S. readers liked a story that made them weep (Veríssimo to Angèle Gingras, 31 May 1941). In 1940, O Diário, a newspaper in Recife, conducted a survey of its women readers and found that Veríssimo was the favorite Brazilian author among the women who responded (Altamira Cunha [a journalist working for the newspaper] to Érico Veríssimo, 23 maio 1940, Acervo do EV, IMS).
} 
American writers, declined Veríssimo's Caminhos Cruzados because "its technique is too discontinuous; its plot is thin; it has too many characters." The style would not be suitable for an American public. ${ }^{27}$

Farrar and Rinehart declined to publish Veríssimo, as did Harper and Brothers. Thornton Wilder had personally asked his editor at Harper and Brothers to look at Saga, Veríssimo's Spanish Civil War novel. Harper's initial response to the book was enthusiastic, but editors questioned whether, given the new world war, readers were still interested in stories set during the Spanish Civil War. They thought Saga could do well if it were published after other books first appeared and Veríssimo's reputation was established in the United States. Knopf also decided against publishing Veríssimo. Knopf's editors provided no explanation for their decision. Blanche Knopf, who typically made the final choice of books the firm selected from Latin America, preferred work with plenty of folkloric and/or mythic elements in the storytelling. She had already rejected publishing the work of Jorge Luis Borges because it was too urbane, too full of literary tricks, and divorced from the elements and popular culture that many intellectuals in the United States took as the essence of Latin American culture. In 1941, the winner of the first annual prize for "best Latin American novel" to be translated into English was Peruvian Ciro Alegría's Broad and Alien is the World (El mundo es ancho y ajeno), a stron-

Hanke's report was negative: Verissimo's work
was untypical of literature in South America and
his picture of southern Brazilian society did not
sufficiently distinguish Brazil from other countries.

gly written story of a violent struggle between an indigenous community in the Andes and white politicians and businessmen who want to integrate a rural region into the national political and economic system. Veríssimo's novels generally lacked images of overpowering nature or popular folklore preserving a purer, premodern way of life, the trademarks of the several dozen novels from Spanishspeaking America translated into English in the 1920s and 1930s.

The most positive response came from Macmillan, where Veríssimo had developed good personal relationships with Doris Patee, the children's book editor, and with Theodore Purdy, who, competent in eight languages, handled acquisitions of foreign books for the firm. Purdy hoped to shepherd one of Veríssimo's books through his firm's review process, but, immediately after Pearl Harbor, he took a leave of absence to work with the OSS (Office of Strategic Services, the precursor to the CIA) in Washington. Macmillan turned then to Lewis Hanke, a specialist in history of the Spanish colonial period and director of the Hispanic Foundation in the Library of Congress, for advice. Hanke's report was negative: Veríssimo's work was untypical of literature in South America and his picture

27J. W. Greenberg, Greenberg Publisher, to Érico Veríssimo, 5 February 1941; Frederick Drimmer, Editor, Greenberg Publisher, to Érico Veríssimo, 19 August 1941, Acervo do EV, IMS. 
of southern Brazilian society did not sufficiently distinguish Brazil from other countries. ${ }^{28}$ Hanke's report underscores a point of division in how different groups within the United States defined authenticity and accessibility. What attracted Veríssimo to the State Department's officials who discovered his work was his apparent similarity to popular U.S. writers of the time, authors like Edna Ferber, A. B. Guthrie, or John Steinbeck. His ability to describe contemporary Brazil made his work, in the State Department's opinion, more accessible to U.S. readers, and his intercultural skills could contribute to securing popular support in the United States for an alliance with Brazil and a significant number of U.S. troops being based there. Veríssimo had a talent for overcoming cultural differences, which would help his readers discover shared histories and shared interests. For reviewers like Lewis Hanke, literature published in the United States should help readers understand the profound differences that existed between the United States and its southern neighbors, differences that required professional scholarship to elucidate. Robert E. Luckey, surveying Brazilian novels available in English, complained that Veríssimo's work was "less illustrative of a variety of Brazilian personalities."29

Negative readers' reports might have been the end of the story, but Veríssimo had several important advocates, fellow writers Thornton Wilder, John Dos Passos, and Robert Nathan, the latter at the time the author of an extraordinarily popular novel, A Portrait of Jenny. Wilder and Dos Passos used their prestige and Nathan, his sales figures to write directly to publishers insisting that they give Veríssimo's work another reading. Additionally, Philip C. Jessup, director of the Carnegie Endowment for International Peace, took up Veríssimo's case. In one letter, Jessup praised a children's book Veríssimo had written on the history of Brazil, The Adventures of Tipicuera:

It is an inspired little book [...] [on] the last page [...] [he has] phrased most admirably the objectives of this Endowment, and indeed my own personal ambitions since I ended as a soldier in the last great war of 1914-18. ${ }^{30}$

Endorsements from writers and public figures like Jessup were important to keeping interest alive, as in practical terms were the efforts of State Department's officials to facilitate contacts, but ultimately, Veríssimo required an internal champion within a press, someone like Theodore Purdy at Macmillan, someone whose enthusiasm could override the hesitations of his colleagues.

Much of what Veríssimo experienced was par for the course in the publishing business. Personal connections have long been important for authors to receive full consideration of their work. In an industry where it is difficult to project the outcome of any given product, "gut reactions" not precise calculation guided decision making. Hanke's report to Macmillan sapped the excitement that the editors had felt at first for a promising new author to add to their list. Now they were unsure whether the material could sell. Simultaneously, Macmillan was pursuing

\footnotetext{
${ }^{28}$ Theodore Purdy, Jr., to Érico Veríssimo, 19 May 1941; Lois Dwight Cole, Associate Editor, the Macmillan Company, to Érico Veríssimo, 4 June 1941; Doris S. Patee to Érico Veríssimo, 5 June 1941; Purdy to Veríssimo, 13 June 1941; Purdy to Veríssimo, 23 June 1941, Acervo do EV, IMS.

${ }^{29}$ Robert E. Luckey, "Materials for a Course in English on Portuguese and Brazilian Literature and Culture," Modern Language Journal, vol. 34, 1950, p. 422.

30Philip C. Jessup, director, Carnegie Endowment for International Peace, Division of International Law, to Érico Veríssimo, 17 August 1941, Acervo do EV, IMS
} 
publication of a novel by Chilean writer Magadalena Petit Marfán, La Quintrala, published in 1942 and advertised by the press as a

tale of seventeenth century Chile, in which a beautiful and wealthy woman, known as La Quintrala, is the central character. Her career of evil and bloodshed, witchcraft and murder is based upon legend. Her fourteen crimes begin with the poisoning of her own father when she is sixteen, and continue thruout her long life. The powers of evil and good are represented on the one hand by her witchlike black nurse, on the other by her saintly confessor. ${ }^{31}$

Macmillan's editors were looking for Latin American fiction that could fit into the popular fiction market of the United States, and Marfán's work, while escapist, fit the identification of Latin America with a folkloric, pre-modern life.

While Veríssimo's books were still in review at Macmillan, Doris Patee wrote about Veríssimo: "Seldom do we find an author from another country writing in another language, who has such an understanding of American interests and problems as you have." But then she added: "My conviction about books from other lands is that they should be clearly representative of that land." She emphasized that Veríssimo's book on Joan of Arc would not be appropriate for translation, since in the U.S. book market the topic needed to be treated by a French, English, or American author. "What we do want are stories that really reflect your country." Then complicating the advice, Patee continued:

We also like stories of everyday life in Brazil, introducing of course incidents, backgrounds, customs, that would be new to our [readers] - but experiences which they can share because they are a part of the life of [people] who are quite like themselves except that they live in another land. This always seems a hard kind of book to get.

Stories from Brazil needed to be specific and unique to the country, but, at the same time, they had to convey universal situations that average readers would recognize with pleasure. In a subsequent letter written while Crossroads was in press, Patee stated:

We often find that there is considerable difference in the appeal of books from other countries [...] here and in their own land. There is certainly something universal about [readers'] interests and there ought to be books that we could exchange but in many cases they do seem too strange and different to meet the same response. I have a feeling that to find a really good sale for a book about Brazil or of stories from Brazil, it would have to be especially written for the American market. ${ }^{32}$

The contradictions in Patee's advice suggest that editors often had no idea why one foreign author - say Thomas Mann or Vicente Blasco Ibáñez, two undisputed star writers in the U.S. book market between the two world wars - sold well, and another did not. Lacking that knowledge, there was no firm basis for predicting

\footnotetext{
${ }^{31}$ From dust jacket of Magdalena Petit Marfán, La Quintrala, translated by Lulu Vargas Vila, New York, Macmillan, 1942

32Doris Patee to Érico Veríssimo, 17 March 1941; Patee to Veríssimo, 12 April 1943, Acervo do EV, IMS.
} 
how any given book would fare, and editors had to/have to rely on their gut instincts whether the particular gamble is worth it or not. Patee was interested in getting Veríssimo to produce a book for Macmillan's children's department, which was one of the biggest in the country. A successful children's book could generate as much income for the publisher and the author as a successful novel, but with considerably smaller production, publicity, and marketing costs. As with his novel, Veríssimo failed to produce a proposal that Patee could endorse, and the idea of his writing children's books for the U.S. market evaporated along apparently with Macmillan's interest in adding him to their author list.

Shortly after the first of Doris Patee's letters quoted above, Veríssimo received a more formal letter from Macmillan declining to offer him a contract. At this point, University of New Mexico Press approached Veríssimo with a proposal that one of his books appear in their Inter-American Translation Series, subsidized by the Carnegie Endowment for International Peace. The publisher admitted that there would be hardly any sales beyond university libraries, but at least the book would be available in English. ${ }^{33}$ Hearing about this offer from friends at the State Department, Theodore Purdy made a quick trip to New York to convince the publisher-in-chief to override the decision of the Macmillan editorial department. Purdy decided that Caminhos Cruzados would be the first book to appear, precisely because it had an urban setting. Purdy liked that Porto Alegre felt similar to many modern mid-sized cities in the United States. The book could be appreciated on its merits as a story not as a symbol summarizing another country. ${ }^{34}$

Reviews of the book when it appeared in English in 1943 validated Purdy's judgment, as did the positive sales figures the book garnered. For the first time in the history of the U.S. publishing business, a novel by a Latin American author went into multiple printings. Critics appreciated the fact that while the characters and the settings were clearly Brazilian, overall situations described were easily accessible. Brazil was not an exotic foreign land, but a society where contemporary people were searching for love and security while struggling with poverty, unemployment, crime, and the persistent danger of war on the horizon. As the New York Times summarized it: "A story of life in a teeming modern city in Brazil, where a group of characters work out their crossed destinies amid problems not unlike our own"35

Veríssimo himself had expected the translation to fail, telling his translator that the lack "of the colorful things that most readers expect in a novel by a Brazilian author - palm trees, Indians, rumba, serenades, the Amazon jungle, and so forth" would doom the edition. ${ }^{36}$ What was the appeal? The Handbook of Latin American Studies, published by the Library of Congress, identified the strength of Veríssimo's work in the author's ability to interweave "human destinies in the life of a provincial city, in this case Porto Alegre, set off by the author's unfailingly beautiful prose style

\footnotetext{
33Joaquin Ortega, School of Inter-American Affairs, University of New Mexico, to Érico Veríssimo, 6 December 1941; Providence Raimond, secretary, School of Inter-American Affairs, University of New Mexico, to Érico Veríssimo, 2 April 1942, Acervo do EV, IMS.

34Theodore Purdy, Jr., to Érico Veríssimo, 31 July 1941; Purdy to Veríssimo, 25 August 1941; Purdy to Veríssimo, 27 October 1941; Purdy to Veríssimo, 31 December 1941; Mary S. Thompson, Publicity Department, the Macmillan Company, to Érico Veríssimo, 16 September 1942; Purdy to Veríssimo, 20 September 1942, Acervo do EV, IMS. 35“Books-Authors," New York Times (16 January 1943), p. 11

${ }^{36}$ Érico Veríssimo to Louis Kaplan, 9 January 1942, Acervo do EV, IMS.
} 
and his deep fund of sympathy and human emotion. ${ }^{37}$ Another reviewer spoke of Veríssimo's writing as marked by "innate modesty, the absolute lack of any hint of pomposity [and an] invincible sense of humor, always ready to puncture any touch of self-importance." ${ }^{38}$

Veríssimo described an agricultural society in upheaval as industrialization and urbanization quickened. He presented the transformation through sets of personal relationships that dramatized the psychological stresses of sociological processes. Given the centrality of family to the older agricultural order, social stresses played out in the alienation of family members from each other (much as Veríssimo's parents had separated in 1922) and the development of new expectations in which women and children could claim greater autonomy. Veríssimo's novels explored the deeply personal struggles marking the quest for new types of ties. Happiness, depression, love affairs, divorces, family feuds were indicators of social states in transition. ${ }^{39}$ In Um Lugar ao Sol, a local boss murders the father of the main character. Her mother moves with her children to the city. The daughter emerges as the novel's central character as she is torn between her yearning for the solidarity of life in the countryside and the personal freedom she discovers in the city. This was a formula consistent with many a Hollywood film and many a middle-brow novel, most famously at the time Margaret Mitchell's Gone with the Wind. In his stories of families in stress, Veríssimo celebrated the lives of men and women forced to discover their latent possibilities. The mixture of utopian and sociological aspects supported what one of his reviewers in the United States called

\begin{abstract}
a dream of the possible oneness of all humankind, united in the bonds of mutual comprehension, peaceful cooperation, and social labor, with the banishment of injustice and selfish ambition. In brief we here draw near to the vast problems confronting the world today; and these problems are treated in the spirit of that great-heartedness which Veríssimo, the biographer, found so admirable in his Jeanne d'Arc. "Pode ser que tudo isso seja apenas um grande sonho. Mas sonhar também é humano".40
\end{abstract}

\footnotetext{
${ }^{37}$ Annotation for Érico Veríssimo, O Resto é silencio, Handbook of Latin American Studies, vol. 9, 1944, HLAS Item\#: re464267, online at http://lcweb2.loc.gov/hlas/.

${ }^{38} \mathrm{~L}$. L. Barrett, review of an edited version of Gato preto em campo de neve prepared for Portuguese students in the United States, Hispania, vol. 32, 1949, p. 265.

${ }^{39}$ For more on this argument about the relation of family and social transformation in Veríssimo's work, see Ligia Chiappini Moraes Leite, Modernismo no Rio Grande do Sul: Materiais para o seu estudo, São Paulo, Instituto de Estudos Brasileiros, 1972; Ligia Chiappini Moraes Leite, Regionalism e modernismo: O caso gaúcho, São Paulo, Ática, 1978; B. A. Richards, Érico Veríssimo: The Brazilian Novels Assessed in the Context of Modernism and Latin American Fiction, London, King's College, University of London, 1981; Maria Antonieta Antonacci, Rio Grande do Sul: As oposições e a revolução de 1923, Porto Alegre, Mercado Aberto, 1981; Luiza H. Schmitz Kleimann, Rio Grande do Sul, terra e poder: História da questão agrária, Porto Alegre, Mercado Aberto, 1986; Sandra Jatahy Pesavento, A burguesia gaúcha: Dominação do capital e disciplina do trabalho, Rio Grande do Sul 1889-1930, Porto Alegre, Mercado Aberto, 1988.

${ }^{40}$ Annotation for Érico Veríssimo, Olhae os lyrios do campo [sic, should be Olhai os lirios do campo], Handbook of Latin American Studies, vol. 4, 1938, HLAS Item\#: re394248a. Brazilian writers of the 1920s and 1930s are generally conceived of as rejecting the Francophile culture of the so-called "Old Republic" (1889-1930) by embracing either modernism with a focus on exploring the unique characteristics of Brazilian nationality or regionalism, which also explored Brazilian identity but by returning to the cultural and social roots of each state. Veríssimo can be seen as operating in the intersection of modernism and regionalism. He was familiar with literary trends in Europe and North America, but with a stronger inclination towards work written for a broad middle-class rather, while his subject matter critically explored social relations in Rio Grande do Sul. That said, the framework poorly describes Veríssimo's goals as a writer and his position in national letters. See Wilson Martins, The Modernist Idea: A Critical Survey of Brazilian Writing in the Twentieth Century, New York, New York University Press, 1970, Antônio Cândido, On Literature and Society, Princeton, Princeton University Press, 1995, Roberto Schwarz, Misplaced Ideas: Essays on Brazilian Culture, London, Verso, 1992.
} 
Macmillan released a new Veríssimo novel every two years, and agreed as well to publish a book by him on the history of Brazilian literature. They decided to forego any further government assistance with translation because the bureaucratic requirements delayed publication, and the editors felt that, with the positive reception Crossroads had received, sales of new titles would easily cover translation costs. ${ }^{41}$ A measure of Veríssimo's commercial success in the United States is that he was the only Latin American author to have more than two titles published between 1940 and 1967, during which time Macmillan released eight separate books by him, a record that exceeded all other Latin American authors in the United States book market before 1970, when there was a sudden explosion of titles by Latin American authors in English translation. ${ }^{42}$

Reviewers with occasional exceptions praised Veríssimo for his story-telling abilities and his understanding of the "human condition." The reviewer for the Chicago Tribune lauded Crossroads for being "Brazilian in detail, universal in emotion." Veríssimo, the reviewer noted, was said to be the most popular novelist in South America, and "Crossroads with its skillful weaving together of five stories showed why." ${ }^{43}$ William Du Bois, reviewing the book for the New York Times, compared Veríssimo to Theodore Dreiser: "Both writers have same super-abundant vitality, the same blunt approach; both pour out their story like over-charged dynamos, and let the pieces fall where they may." Du Bois commended Veríssimo for having greater control over form and content than Dreiser. Addressing the Brazilian setting, Du Bois located Porto Alegre as the capital city of the southernmost state of Brazil, adding that

Érico Veríssimo's novel does more than burnish one's geography, far more than bring a strange corner in a strange land alive for us. Though his whirwind tour of Porto Alegre lasts only five days, it covers the city from slum to boulevard. Senhor Veríssimo moves his characters with such practiced ease the reader forgets how much ground he takes in. But when he puts the book down, he will realize that Porto Alegre is not so different from Jacksonville [Florida, earlier noted in the review as exactly as far from the equator as Porto Alegre]. Crossroads is definitely a solid contribution to a good neighbor policy. [...] Without a single false climax, without rising above an artless reportorial style [Veríssimo] can focus one's interest from the start, and hold it fast, as he manipulates a teeming dramatis personae. The smallest character comes vibrantly alive under his hands, though he does no more than sketch in an outline. [...] Though [Veríssimo] offers no salvation to ease man's burden, he understands man to the core; he is by turns profound as a saint in armor and cynical as a café wit; always, he is as easy to read as a child's primer. Crossroads is a long novel, but this reviewer only wishes it were longer. He is not ashamed to admit that he devoured it in a sitting. ${ }^{44}$

\footnotetext{
${ }^{41} G$ George P. Brett, Jr., President of the Macmillan Company, to Érico Veríssimo, 6 August 1943, Acervo do EV, IMS. ${ }^{42}$ Even with the "boom" after 1970, to this day only fourteen Latin American authors have had a number of titles in English equal to Veríssimo: Jorge Amado, Miguel Angel Asturias, Jorge Luis Borges, Ernesto Cárdenal, Julio Cortázar, José Donoso, Carlos Fuentes, Gabriel García Márquez, Joaquim Maria Machado de Assis, Pablo Neruda, Octavio Paz, Manuel Puig, César Vallejo, and Mario Vargas Llosa.

${ }^{43}$ F. B., "Books: South American Writes a Tense, Dramatic Story," Chicago Tribune, vol. 17, February 1943, p. 23. ${ }^{44}$ William Du Bois, untitled review, New York Times, 24 January 1943, Book Review Section, p. 6.
} 
This review was particularly auspicious for Veríssimo's debut as a novelist in the United States. Du Bois joined New York Times staff in 1926 and quickly rose to become the editor-in-chief of the newspaper's book review section, a position he held for three decades. Du Bois's review of Crossroads established a language for discussing Veríssimo's work that most other reviewers echoed and continued to use with subsequent translations of his books. Significantly, both Library Journal and Booklist recommended that libraries acquire the book, important for assuring a book's commercial success. ${ }^{45}$ Reviewers' evaluations of Veríssimo's books over the next 15 years again and again stressed his delightful writing style in excellent translations, his powerful understanding of the human condition, his clever ability to weave together several stories into a satisfying unity, his exploration of human frailties made sympathetic "by a deep feeling for the mystery of human existence." ${ }^{46}$ While Crossroads and The Rest is Silence had urban settings, Consider the Lilies of the Field took place in a fictional small town in the central agricultural region of Rio Grande do Sul. This novel centered on two doctors, a husband and wife, working together in a small practice struggling with the limitations and the inequities of rural life during the Great Depression, a story that also found resonance with reviewers in the United States and attracted readers there as it had earlier in Brazil. Encouraged by his editors at Macmillan to develop an epic story of life in southern Brazil, Veríssimo began working on a long novel (eventually seven volumes in the Portuguese-language edition) that traced the fate of a family in rural Rio Grande do Sul from 1745 to 1945 . With the publication of the first section, O Continente, in English in 1951, under the title Time and the Wind, Herschel Brickell, writing in the Saturday Review of Literature, hailed Veríssimo as the single most important writer working in Latin America and the new book as "as fine a novel as Latin America has yet produced at any time." ${ }^{47}$

As in Du Bois's review of Crossroads, reviewers consistently noted the specifics of the Brazilian locations, typically followed by a delighted exclamation that the scenes, themes, places, and people were all readily accessible. Veríssimo's characters struggle with how to pay their rent or get a sick child treated, how to escape parental controls, how to compensate for a marriage without love. In a passage from Crossroads, the narrator observes that in his city,

streetcars and autos roll by, men walk and struggle, dramas are happening, there are hidden tragedies, cries of pain and joy; poets write verses to the moon, vagabonds stroll through the gardens, jobless men drift along aimlessly, and geniuses and imbeciles are being born. ${ }^{48}$

The translator of Crossroads, a postal clerk from Chicago who taught himself Portuguese by locating new novels that seemed interesting to him and then translating them into English, did not attempt to Americanize the settings or the language. He repeated the Portuguese forms of address that Veríssimo had used, such as senhor, dona, and seu, each with a distinct set of social registers meaningful to

\footnotetext{
45Library Journal, vol. 67, 1 November 1942, p. 952; Booklist, vol. 39, 1 March 1943, p. 275.

${ }^{46}$ Granville Hicks, untitled review of Time and the Wind, New York Herald Tribune, 8 November 1951, Book Review Section, p. 7.

${ }^{47}$ Herschel Brickell, untitled review of Time and the Wind, Saturday Review of Literature, vol. 34, 22 September 1951, p. 15.

${ }^{48}$ Érico Veríssimo, Crossroads, translated by L. C. Kaplan, New York, Macmillan, 1943, p. 106.
} 
Brazilians addressing each other, but without slowing down the narrative to explain the nuances of each usage. Attentive readers over time might intuit how specific terms function in a society with a somewhat more defined social hierarchy than the United States, but readers who did not see that element would still be reminded that, despite many similarities, there were fundamental differences between the societies of Brazil and the United States. Readers might well have noticed that many of the characters base their actions on standards set in the United States and Europe, with often ridiculous results; the effects are clear but the book did not explain slavish imitation of the north as a feature of middle-class and elite life in Brazil, nor did the translator make any effort to add any further explanation. Another theme in the book that could easily be misunderstood by most U.S. readers was the exercise of patronage in Brazilian society. The plotline of the book revolves around two characters that lost their jobs because their employers owed favors to more powerful people with "protégés" in need of positions. To maintain good relations with people whose assistance could be important in the future, the employers invent reasons to fire employees who lacked protective patrons. Brazilian readers understood well how systemic clientelismo functioned in their country, and Veríssimo's treatment underscored the human costs without needing to explain further. Readers in the United States understood that employers in their country on occasion were known to fire employees to give preferential treat-

Between 1943 and 1945, my estimate based
on Veríssimo's archives and records in the State
Department is that he spoke to no less than 200
groups, traveling to all parts of the country to
address civic clubs, women's clubs, university groups,
businessmen's associations, and religious institutions.

ment to friends of friends. U.S. readers, however, would not understand from reading the book that the problem in Brazil was a question of deeply rooted social structures, not simply of personal moral choices, nor would they know that the lack of a patron could make finding a new job difficult to impossible. ${ }^{49}$

Such information would have had to be added into the book, as would more information about the political situation lying behind the occasional discussions in the book about influence and public policy. The price of greater sociological precision might have been a narrative that flowed less fluidly, and the translator chose to focus on the story. This was not the choice of Samuel Putnam, a noted

\footnotetext{
${ }^{49}$ On clientelismo in Brazil, see Luiz Henrique Nunes Baía, O poder do clientelismo: Raízes e fundamentos da troca política, Rio de Janeiro, Editora Renovar, 2003; Edson de Oliveira Nunes, A Gramática Política do Brasil: Clientelismo e Insulamento Burocrático, Rio de Janeiro, Jorge Zahar Editora, 2003; Paul Cammack, "Clientelism and Military Government in Brazil," in Private Patronage and Public Power: Political Clientelism in the Modern State, ed., Christopher Clapham, London, Frances Pinter, 1982; José Murilo de Carvalho, "Barbacena: A Família, a Política e uma Hipótese," Revista Brasileira de Estudos Políticos, vol. 20, 1966, p. 153-194; Luis de A. Costa Pinto, Lutas de Família no Brasil: Introdução ao seu Estudo, São Paulo, Editora Nacional, 1949; Nestor Duarte, A Ordem Privada e a Organização Política Nacional, São Paulo, Editora Nacional, 1939; Linda Lewin, Política e Parentela na Paraíba: Um Estudo de Caso da Oligarquia de Base Familiar, Rio de Janeiro, Record, 1993; Sérgio Buarque de Holanda, Raízes do Brasil, São Paulo, Companhia das Letras, 1995; originally published, 1936.
} 
Latin American scholar, when he translated Jorge Amado's novel of social strife in the cocoa plantation region of Bahia, Terras do sem fim, published under the title The Violent Land by Knopf in 1945 to generally poor reviews. Amado's book in translation could instruct its readers on the complexities of the political and social movements in Brazil in the 1930s and 1940s, potentially valuable information given the importance of Brazil as an ally in the war. Veríssimo's book in translation echoed ideas in the United States that politicians are a corrupt and insincere lot, without establishing the different countries have distinctive forms of political corruption. Given the respective political stands that the two authors took - Amado was a militant in the Communist Party, and Veríssimo believed that "o esforço dos homens de boa vontade, sem violência nem fanatismo, possa igualar as diferenças sociais" 50 - the strategies adapted by the two translators may well have conveyed what mattered most to their authors.

\section{Good Neighbor Ambassador}

In early 1943, as Crossroads was about to appear, Richard Pattee contacted Veríssimo with an invitation to spend one or two years in the United States, lecturing on Brazilian literature at an American university. Veríssimo was unsure if he should accept the offer, given that he had ended his formal education at an unusually early age and he had no experience as a teacher in Brazil. Nonetheless, the idea of spending a longer period of time in the United States appealed to him. He hoped he would be able to follow trends in the U.S. publishing business more closely and make better use of the contacts he had developed in the United States to land the Portuguese-language rights for a wider range of U.S. best-sellers. Despite that goal, he and his wife decided they wanted to live in California rather than on the East Coast, opting for a part of the country that had struck Veríssimo as culturally more comfortable for him and his family. ${ }^{51}$

The State Department arranged an appointment at the University of California, Berkeley. Veríssimo was one of 157 visiting professors whose stays at U.S. colleges and universities the federal government subsidized. ${ }^{52}$ Veríssimo taught an undergraduate course on Brazilian literature in English three days a week. His class was so successful that the room had to be changed to accommodate the number of students who wanted to enroll. He missed home, he reported, but living in the United States was still an adventure. That no one challenged his credentials as a teacher was enlightening and provided insight into an aspect of life in the United States that he thought explained the flexibility of the society:

\footnotetext{
${ }^{50}$ Érico Veríssimo, Caminhos cruzados, São Paulo, Companhia das Letras, 2005, p. 153; translated by L. C. Kaplan in Crossroads as "a marvelous day when the efforts of men of good will will level all social differences, without violence or extremes” (p. 176).

${ }^{51}$ Érico Veríssimo to Richard Pattee, 13 January 1943 and 21 May, 1943, Acervo do EV. IMS. In June 1942, he had written a friend in the United States that he hoped to spend one or two years in California after the war (Érico Veríssimo to Angèle Kathleen Gingras, 15 June 1942). For report from the University of California on the expectations of the Department of Spanish and Portuguese regarding Veríssimo's visiting professorship, see S. G. Morley, Chair of the Department of Spanish and Portuguese, University of California, Berkeley, to Harry H. Pierson, Division of Cultural Relations, U.S. Department of State, 26 May 1944, in folder of correspondence received 1944 pertaining to the United States of America, in archives of Secretaria de Estado das Relações Exteriores, Arquivo Histórico do Itamaraty.

52. Manuel Espinosa, "Exchange of Professors Between the United States and Other American Republics," The Americas, vol. 3, 1947, p. 535-543.
} 
E no meio de todas essas manifestações, eu só fico a pensar nesta coisa melancólica. Se eu dissesse que na minha cidade eu não poderia ser professor pela simples razão de não ter um titulo de doutor e não ser católico praticante, eles cairiam para trás de surpresa. ${ }^{53}$

He wanted to stay long enough to get past the superficial impressions a traveler makes and reach a point where he could understand why this country functioned so well even in the midst of so much obvious chaos. This question was to be the theme of his second book on the United States, Volta do Gato Preto, but the answers eluded him and important parts of his experience were omitted entirely even though the book purported to be a record of his everyday life. Veríssimo may have discovered the truth of Lewis Hanke's warning to another Brazilian writer on his arrival in the United States: "If you are going to write a book about a country, three months is the right period. Either that, or you have to live in it for ten years". The "shock of novelty" generates an initial reaction that, Hanke thought, is lost in a struggle to understand the contradictions deeply embedded in the patterns of everyday life. ${ }^{54}$

On his second, more extended stay, the State Department arranged tours for him where he could address a broad variety of community groups on Brazil and his personal hopes for Pan-Americanism. Between 1943 and 1945, my estimate based on Veríssimo's archives and records in the State Department is that he spoke to no less than 200 groups, traveling to all parts of the country to address civic clubs, women's clubs, university groups, businessmen's associations, and religious institutions. His audiences at any given event could be as small as twenty, more often were in the lower hundreds, and at one event six thousand people showed up to hear him speak. He appeared on radio, and he was invited to christen the destroyer named after Brazilian diplomat Baron Rio-Branco.

Interviewed on a radio program in Sacramento, California, Veríssimo spoke of how much everything in California reminded him of his own home:

The sunlight - the woods smell in the air - the plane and magnolia trees and even the faces of people. Another thing, they don't rush - that's a Brazilian trait. [...] people on the East Coast and New England are a bit different [from Brazil], but not in California. You have so many foreign influences and a similarity of climate and landscaping makes Brazilians and Californians rather alike. You know, I believe that geography and environment has a lot of influence on the soul of a people..$^{55}$

As always, the interviewer asked him to talk about race relations in Brazil. He spoke of the continuing amalgamation of humanity in Brazil, but even with racial differences, the "psychology" of Brazilians was shared across races, and there were no distinctions by race in how people spoke Portuguese. With a bit of humor, he added that the special situation of Brazil was evidence that God was a Brazilian. "Now, what am I going to answer to that!", the interviewer exclaimed.

\footnotetext{
${ }^{53}$ Érico Veríssimo to Henrique Bertaso, 8 November 1943, Acervo do EV, IMS

${ }^{54}$ Remark from an interview with Brazilian historian Sérgio Buarque de Holanda, in which he recalls a conversation in 1941 when Buarque de Holanda visited the United States at the invitation of the State Department. See Sérgio Buarque de Holanda and Richard Graham, "An Interview with Sérgio Buarque de Holanda," Hispanic American Historical Review, vol. 62, 1982, p. 14.

${ }^{55}$ Érico Veríssimo interviewed by Eloise Keeler on the radio program "At Your Service" KFBK, 1530 (Sacramento, California), 9:00 AM, Tuesday, 3 July 1944, transcript in Acervo do EV, IMS.
} 
"Don't answer it — just believe!" Veríssimo insisted, and the interviewer responded: "They say we Californians claim everything is bigger and better here, but we don't make quite such amazing statements as you do."

The subject shifted to Brazil's contribution to the war effort. Veríssimo spoke of his long history of writing against the Nazis, as well as threats he received from Brazilian fascists. Since Brazil had joined the war, its navy patrolled the South Atlantic taking out German submarines and destroyers, their soldiers were fighting in the Italian campaign, and Brazilian "G-men" had rounded up German saboteurs and their Brazilian agents. Brazil was performing its duties in the war, he assured his listeners, but warned them of the moral saboteurs who were actively trying to break up the U.S.-Brazilian alliance:

Axis sympathizers try to tell Brazilians that you Americans are just an imperialist country and that you are not interested in pure friendship. You just want markets for your products. I think we must at all costs try to promote a better understanding between North and South America.

When asked how to achieve "better understanding," Veríssimo advised:

Through the work of honest, clever, and good willing writers who are more interested in serving inter-American relations than to make sensational statements or just best sellers. By sending down to Brazil students and women and not only big shots. Increasing the visits of women between both countries was important because "when [women] like a place they will talk and talk and talk in a very effective way about that place. And they generally are not so much interested in business, but in human relations. ${ }^{56}$

Veríssimo's talks were humorous, a point that he himself underscored: a nation in which average citizens have a well-developed sense of humor will not turn towards fascism or communism. The people of the United States and Brazil did not take themselves too seriously, so neither country was in danger of being taken over by a radical movement, but he told his U.S. audiences that, in both countries, there were leaders in business and politics who took themselves too seriously. If there were ever problems in the relationship of the two nations, the self-serious men at the top would be the cause of the problem. ${ }^{57}$ In an address to the Town Hall of Los Angeles, Veríssimo warned his audience that relations with Brazil could easily deteriorate. He warned that the military, many leaders in the Catholic Church, and German-Brazilian community groups spoke of the United States as materialistic, irreligious, immoral, and imperialistic. How U.S. motion pictures and visitors presented themselves was important, as the average Brazilian judged a person by what they saw

\footnotetext{
${ }^{56}$ Interview with Érico Veríssimo on the program "At Your Service" KFBK, 1530 (Sacramento, California), 9:00 AM, Tuesday, 3 July 1944, transcript in Acervo do EV, IMS.

${ }^{57}$ Bess M. Wilson, "Brazilian Views Told by Author," Los Angeles Times, 6 November 1944, p. A6. In sharp contrast to Veríssimo's assessment, Selden Chapin, a career foreign service officer and assistant chief of the Division of the American Republics in the Department of State, had penned a memorandum advising the department that U.S. visitors to Brazil should avoid humor as Brazilians did not take public speakers who used jokes in their talks seriously (Chapin, "Need of Cultural Relations with Brazil," 5 April 1937, NA/DS/RG59, Lot Files, Entry 209, Office of American Republic Affairs, Its Predecessors, and Its Successors, Memorandums Relating to General Latin American Affairs, Country File B24).
} 
rather than by the gossip they heard. He urged his listeners to give more thought about how others viewed their country. ${ }^{58}$

Veríssimo's talks were part of a large program aimed at influencing public opinion within the United States. Scholars who have examined the film-distribution program that the Office of Inter-American Affairs established have estimated that, every month, approximately five million people in the United States saw "OIAA-sponsored films on Latin American topics in schools, colleges, community centers, club houses, churches, and elsewhere." The goal was

to inspire a 'sympathetic understanding' of Latin America and a positive interest in the region as an object of study, travel, or investment. More specifically, it meant to instill a positive disposition toward Roosevelt's Good Neighbor policies and an appreciation of the region's strategic and economic importance for the United States. ${ }^{59}$

Speaker programs allowed for audiences to develop a more personal understanding of another country, provided the speaker had an understanding of audiences and what made them respond sympathetically. Veríssimo had proven talent in that direction, which made him a valuable speaker for the Good Neighbor Program, particularly in areas of the country that had been bulwarks of isolationist sentiment. ${ }^{60}$

Veríssimo's visit to Abilene, Texas, in March 1945 can provide a sense of what the Good Neighbor Program meant on the ground, and not simply as a geopolitical stratagem. Abilene was then a medium-sized town of 50,000 in the middle of the cattle and petroleum country of northwest Texas. It sits on the wind-swept Great Plains in the heart of Bible Country. At the time of Veríssimo's visit, Abilene was not a cosmopolitan community, nor was it a place of great diversity. Some 600 people showed up for an afternoon's activities at Abilene Christian College. The meeting ground was decorated with U.S. and Brazilian flags, as well as cowboy gear from Texas and Brazil. After singing the "Star Spangled Banner," the audience was led in singing the Brazilian national anthem in English translation. A program of American and Brazilian folk songs followed. The audience was again encouraged to sing along with the translated lyrics projected onto a screen, above the original texts. Two songs were performed in Portuguese, so the audience could get a sense of how they sounded in the original language.

After the cultural program, Érico Veríssimo presented a fifty-minute talk with slides entitled "Brazil, the Gentle Giant." Veríssimo's talks were humorous, but he also used the opportunity and the good will he seemed to generate from his listeners to present them with his friendly criticisms of the United States. He insisted on talking about the long history of racial hatred and the damage that segregation laws did to the nation. Texas was a Jim Crow state, but Veríssimo gave the same message

\footnotetext{
58"Relations with Brazil Reported Deteriorating: Brazil Cools toward U.S.," Los Angeles Times, 14 November 1944, p. A1.

${ }^{59}$ Gisela Cramer and Ursula Prutsch, "Nelson A. Rockefeller's Office of Inter-American Affairs (1940 - 1946) and Record Group 229," Hispanic American Historical Review, vol. 86, 2006, p. 795.

${ }^{6}$ Seth Garfield has noted that the America First Committee, the primary isolationist organization in the United States, had embraced pan-Americanism as an alternative to war in Europe and Asia. A pan-American division of labor could provide the United States with tropical commodities such as rubber that were essential to high levels of industrial production but which were coming from European colonies in Asia and Africa. See Garfield, "A Amazônia no imaginário norte-americano em tempo de guerra," Revista Brasileira de História, vol. 29, 2009, p. 19-65.
} 
there as in California or New York. He compared the situation in the United States with his own country's legacy of racial mingling, but he did not pretend that Brazil had achieved full racial equality. He also talked about Americans' inclination to overwork and material possessions, as well as the misinformation in the popular media about Latin America, using examples of recent portrayals of Brazil in movies or the press. He hoped that communication between the two countries, such as represented by the day's event, would increase, and Americans would quickly become as familiar with Brazil as they were with England or France.

At the end of his talk, he received a thundering ovation from the crowd. The event concluded with a buffet of "typical Brazilian food" (menu not identified, but churrascaria would have been comfortably similar to Texas barbecue), and a chance for conversation with the speaker. Veríssimo thought the day was a big hit. The president of the college offered him a one-year contract, not uncommon at the end of his performances. Over a three-week tour of Texas, Oklahoma, Kansas, and Kentucky, Veríssimo spoke at 19 locations to unusually enthusiastic audiences. Veríssimo built a sense of personal connection for average American citizens with Brazil. Towns like Abilene, Texas, were central to the program's long-term goals because distrust of the larger world came easily there, and the citizens of this and similar provincial communities needed to be won over if the new role of the United States as leader of the postwar world was not to be a victim of deeply engrained isolationist sentiments. ${ }^{61}$

In mid-1945, as time came to return home, Veríssimo considered whether he might not be happier staying in the United States. His relations with his U.S. publisher were excellent. In 1943, he started sketching the outlines of the epic novel generally recognized as his masterpiece, $O$ Tempo e $o$ Vento. ${ }^{62}$ Macmillan editors strongly encouraged him in his plans to write a historical novel covering the settlement and development of Brazil, assuring him that readers worldwide loved ambitious sagas. At his very first meeting with Macmillan editors in 1941, they brought up Margaret Mitchell's Gone with the Wind and Richard Llewellyn's novel of a Welsh coal mining family, How Green Was My Valley, as models for the successful collaboration between publisher and author that could transform an unknown writer into an international success, with Hollywood film adaptations helping to sell the books in every part of the globe. Why could not a Brazilian author telling the authentic stories of his own people become equally famous?

\section{Alliances end, relations deepen}

The Brazilian government's postwar assessment of cultural exchange programs with the United States was largely positive. A report prepared for the Secretaria de Estado das Relações Exteriores in 1948 stressed the growing availability of accurate information about Brazil in the United States after a decade of sustained effort by the U.S. government. The report noted the publication of books that summarized Brazilian laws related to business and labor, as well as works that explained the principles of Brazilian legal system. More accurate information was available in

\footnotetext{
61Érico Veríssimo to Henrique Bertaso, 14 February 1945; 17 April 1945.

${ }^{62}$ In his memoirs, Veríssimo said he first thought of writing a saga of Rio Grande do Sul in 1935 during the centennial of the Guerra dos Farrapos (the "Ragamuffin" War), but required more time to figure out how to frame the story (Érico Veríssimo, Solo de clarineta: Memórias, vol. 1, Porto Alegre, Editora Globo, 1973, p. 288).
} 
the United States on Brazilian history, geography, society, and economy. The report's author(s) noted significant expansion of programs for learning Portuguese and stressed that U.S. students studying the language were learning Brazilian vocabulary and grammar. Brazilian artists, musicians, and writers were better known, giving Americans a feeling for their nation and its culture. The survey concluded that cultural exchange had improved understanding of Brazil within the United States and that cooperation with these programs should continue. ${ }^{63}$

Throughout the postwar years, Brazil industrialized rapidly, but living standards for many stagnated while poverty in many states deepened. The postwar global economy exacerbated many of the underlying inequities long present in Brazil. The urban middle-class had also become a victim in the process, experiencing a sharp drop in disposable income. The effects on the publishing business in Brazil were particularly dramatic. Publishers had prospered during the war years, but their business grew increasingly precarious after 1945. Editora Globo was forced to reduce costs, particularly by cutting money for translations. Brazilian foreign exchange controls limited royalty remittances, and U.S. and European publishers decided that the Brazilian market had little to offer them. Between 1945 and 1960, the number of foreign books translated into Portuguese for publication in Brazil dropped by 80 percent ${ }^{64}$ Editora Globo had grown before World War II by introducing Brazilian readers -primarily the urban middle-class - to contemporary literature in Europe and North America. Globo responded to the postwar crisis essentially by eliminating foreign literature from its lists, a move that did not lead to an increase in publication of national authors. Globo's new strategy for survival was to switch to the publication of textbooks, technical books, and reference books, such as dictionaries. Book buyers were less likely to be individual readers, particularly as the middle-class was in economic crisis. The expanding educational system, government agencies, and private corporations became the primary buyers of books in the country. Besides technical books, Globo, along with most other Brazilian publishers, increased translation of world classics, books of historic importance in the public domain and needing only a one-time fee for the translator. These books served the academic market, as well as a growing readership with somewhat limited discretionary spending but desirous of becoming more familiar with the classics of western civilization. There was also increased publication of Brazilian historical documents, also not covered by copyright, and of interest to libraries. ${ }^{65}$

Veríssimo's responsibilities at Globo required less time on his part. He could devote himself to writing. His books continued to sell reasonably well, but royalty income declined and was, at times, sporadic. Royalties received from Macmillan for U.S. and other foreign sales took on increasing importance, even if not involving large sums, in maintaining a modest but comfortable middle-class standard of living for him and his family. In the 1950s, however, the mass-media industries in the United States were also going into crisis. Hollywood was in rapid decline as more consumers stayed home to watch television. Mass-circulation magazines like Life were experiencing a steady downward shift in subscriptions

63File 6921/914, Indice: Conhecimento sobre o Brasil nos Estados Unidos, 19 November 1948, in archives of Secretaria de Estado das Relações Exteriores, Arquivo Histórico do Itamaraty.

${ }^{64}$ Laurence Hallewell, Books in Brazil: A History of the Publishing Trade, Metuchen, New Jersey, Scarecrow Press, 1982, p. 235.

65/bidem, p. 235, 275, 334 
and advertising income. Book club membership was falling. The book industry no long could rely on methods developed during the interwar period to move its merchandise. Through the beginning of the 1950s, the industry trade journal Publisher's Weekly explored the range of new strategies that publishers were trying to maintain and grow their sales. These included increased reliance on national book prizes to identify titles that readers should want to read and more effective display of books in stores. A major lesson publishers drew from changing reader behavior was that readers had to be jolted into reading a book. Good stories and strong characters were no longer sufficient. More explicit sex increased sales, but another path to commercial success was to generate controversy about the book or its author. ${ }^{66}$ Veríssimo's increasing anti-communism ironically made him less interesting to critics and readers in the United States. They wanted to read about revolutionary movements in Latin America. Criticism in Brazil that he was an agent of the United States government was a controversy that had no marketable value in the United States, particularly as the Cuban revolution increasingly became the focus for how the United States viewed the continent.

Veríssimo retained close connections to the United States until his death in 1975. He lived in Washington DC for three years in the mid-1950s while serving as director of cultural exchange for the Pan American Union. His novel Noite was adapted into a live television drama produced for "The Alcoa Hour" in 1957, an adaptation he did not think very successful despite the presence of superb actors like Jason Robards and E. G. Marshall. His daughter married a North American, and Veríssimo had three grandchildren living in Virginia. Veríssimo and his wife made regular visits to the North American branch of their family, often staying for months at a time. During these visits, he resumed the routine of traveling around the United States to give talks. He came to feel that U.S. society, despite the immense wealth the country enjoyed, had grown more ugly and cruel after World War II. The leadership the United States provided the "democratic" world had taken a cynical turn, with national ideal invoked but seldom followed. In 1968, he wrote in an article reflecting on the disappointment of the hopes that had moved him in 1941:

Os Estados Unidos emergiram da segunda Guerra Mundial como os líderes naturais do mundo ocidental. Para essa tarefa estavam sem a menor dúvida preparados materialmente [...] No entanto suas elites intelectuais [...] constituem uma classe de párias, de

\footnotetext{
66“"TV Effect on Book Buying Is 'Nil,' ABA Reports," Publishers Weekly (6 January 1951), 21; "Specialists to Confer on Book Use and Reading," Publishers Weekly, 13 January 1951, p. 6-7; "Nation's Business at High Level: 1951 to Bring Retail Boom", Publishers Weekly, 13 January 1951, p. 127-129; "Summary of Events and Trends, 1950, in the American Book Trade," Publishers Weekly, 20 January 1951, p. 221-226; "U.S. Economy Now at Record High: How Will It Affect the Book Trade?" Publishers Weekly, 5 January 1952, p. 21; "Will the 'Award Books' Be Featured in Your Store?" Publishers Weekly, 5 January 1952, p. 40; "Tips for the Bookseller," Publishers Weekly, 16 August 1952, p. 700-701; "Sales Appeal," Publishes Weekly, 13 September 1952, p. 992; "For 1953, Sales Expansion Both Bottom and Top," Publishers Weekly, 3 January 1953, p. 41; "The Promotion of Reading Will Be Vigorous in 1953," Publishers Weekly, 10 January 1953, p. 133; "Summary of Events and Trends, 1952, in the American Book Trade," Publishers Weekly, 24 January 1953, p. 269-272; "Highlights of 1956 News and Trends in the U.S. Book Industry," Publishers Weekly, 21 January 1957, p. 47-60. See also Priscilla Coit Murphy, "'Down with Fiction and Up with Fact': Publishers Weekly and the Postwar Shift to Nonfiction," Publishing Research Quarterly, Fall 1998, p. 29-52; and Evan Brier, A Novel Marketplace: Mass Culture, the Book Trade, and Postwar American Fiction, Philadelphia, University of Pennsylvania Press, 2009, p. 109-115.
} 
marginais praticamente sem voz em assuntos políticos e sociais e principalmente na direção das relações exteriores do país, de sorte que tem faltado uma orientação humanista à gerência americana desta parte do mundo. Na minha opinião o erro inicial e básico de novo Big Leader foi o de imaginar que tudo quanto é bom para os Estados Unidos tem de ser necessariamente bom para o resto do mundo, sem levar em conta fatores étnicos, etnológicos, históricos ou mesmo folclóricos. Imaginaram os estadistas de Tio Sam que o American Way of Life não só podia como devia ser exportado. [...] Ora, as nações, como as crianças, têm a faculdade de se encantarem ou assustarem com suas próprias ficções. Os americanos, que eu saiba, jamais examinaram a sério a sua mitologia. ${ }^{67}$

Veríssimo remained anti-communist, and he viewed the communist revolution in Cuba as a disaster, not as the harbinger of the world's future. The debate that he as an author conducted simultaneously with U.S. society and with the Latin American left took shape in his novel $O$ Senhor Embaixador (Mr. Ambassador), published in 1965, simultaneously in English and Portuguese. Sections of O Senhor Embaixador spoke to enthusiasm among the left for Cuban-style revolutions throughout Latin America. The revolutionary existential demand that all could become "new men" through heroic action led only to dictatorship, Veríssimo ar-

Despite the many supportive things Alfred Knopf
said to Verissimo and to her personally, he
remained deeply offended that Verissimo had done
so well with Macmillan and was happy that the
major Brazilian competitor to Jorge Amado in the
English-language market was in trouble.

gued, more likely of the right than of the left, but in either case a dictatorship that valorized violence over human rights. He viewed the historical trends in both the United States and Latin America as destructive and ultimately nihilistic. Instead of reform, responsibility, and accountability, both cultures were caught up in the vortices of violence that a politics of sheer will inevitably generated. It was a message that confused many critics in the United States. They wanted to see deeper criticism of their own country's policies, not even-handed analysis. Still the book did well, and a Hollywood producer optioned the book with the idea, eventually unsuccessful, of turning it into a film starring Paul Newman.

Veríssimo's next novel, O Prisioneiro (The Prisoner), published in Portuguese in 1967, also sprang directly from his engagement with U.S. society. This story of an American platoon leader who captures and tortures a Viet Cong soldier in Vietnam might have played a role that proponents of cultural exchange had imagined earlier in the $20^{\text {th }}$ century: as the

67Érico Veríssimo, "Gato Grisalho em Teto de Zinco" (artigo de 1968 sobre os Estados Unidos vinte anos depois da Segunda Guerra Mundial), text in Acervo do EV, IMS. 
United States fought out its deep internal divisions over Vietnam and the larger foreign policy directions that war indicated, sympathetic neighbors could contribute to the debate with independent perspectives needed as a reality check. Veríssimo was asking what forces, political and cultural, turned the good soldier of the Second World War into a monster in spite of himself? How did the militarization of a society undermine the norms that encouraged decency and respect for law? A question that clearly pointed to developments in Brazil as the military government, installed in 1964 with U.S. assistance, confronted a leftist guerrilla insurrection and chose to fight it without legal or humanitarian restraints.

In the United States, the questions raised in $O$ Prisioneiro were not considered because the book was never translated into English. In 1966, a multinational corporation purchased Macmillan, relying on new techniques of leveraged buy-outs requiring increased profit margins to pay back the costs of the purchase. New management wanted a smaller author list and insisted on a higher average sale for titles. Over half the authors that Macmillan had published were dropped, Veríssimo included. His New York agent, Lucille Sullivan, from the prestigious and very old Maurice Crain agency, found it difficult to find a new U.S. press for him. She tried placing him with Knopf, Jorge Amado's publisher, but her take was that, despite the many supportive things Alfred Knopf said to Veríssimo and to her personally, he remained deeply offended that Veríssimo had done so well with Macmillan and was happy that the major Brazilian competitor to Jorge Amado in the English-language market was in trouble.

Having failed with Knopf, Sullivan negotiated a contract with Greenwood Press, a commercial publisher that had done well in the social science and legal markets, and wanted to expand into fiction. Greenwood agreed to reprint all of Veríssimo's translations, in both paper and hardback, and to handle his future work. But, as the economic crises of 1969-1971 deepened, Greenwood found itself overextended with its new venture in fiction publishing. The owners were forced to sell the firm to a multinational company, which, in reorganizing the company, eliminated the fiction division entirely. Sullivan then decided to retire, and the Maurice Crain agency closed, another victim of a difficult economic climate. The agency that took over Veríssimo in 1971 had no personal connections with him. The generation of agents, editors, and publishers he had worked with was gone or going. His new agents handled opportunities as they developed, but they had no incentive to save the career of a writer whose heyday, at least in the United States, had passed, and whose books expressed cultural perspectives of an earlier, disappearing generation.

At the end of his life, Veríssimo was thrown back onto the Brazilian market, which had started growing rapidly. He had many readers at home, but he remained disappointed that his readers elsewhere, including in Latin America, were declining as a result of his not having a U.S. press representing him. Veríssimo's success in the United States had always been likely to be temporary because few authors continue to be read generally by succeeding generations. The decline of his reputation parallels that of authors in the United States that he knew and admired, such as Thornton 
Wilder, John Dos Passos, Hendrik Van Loon, or Aldous Huxley. Veríssimo had a moment of fame in the United States in part because his outlook and style fit the expectations of a particular generation of U.S. readers. Additionally, the years 1940 to 1970 remain the apex of U.S. interest in foreign culture as measured by the number of translations published or foreign films seen. An important factor in the decline of translation was a reorganization of the U.S. book market that began in the 1960s as multinational firms took over every major U.S. publisher. Minimum sales required for titles increased. The shifts in the business model that publishers worked with made translations more difficult for editors to approve given the extra costs they involve and persistent questions surrounding how to market unknown writers. Authors like Paulo Coelho or Stieg Larsson can be translated once popularity is established and a marketing scheme developed, but writers whose works are more difficult are seldom marketed to the general public. Within the United States, only academic specialists comment on their work, and their critical analyses likely reinforce corporate conviction that "prestige" authors are unlikely to appeal readers outside the university. Decline in translation has ideological and political effects within the United States. At the very least, it is symptomatic of the relative irresponsibility of the nation's global citizenship. But U.S. political and economic elites have become increasingly irresponsible to their own national public, as well. Perhaps given how leadership has grown accustomed to acting without effective public accountability, it should not be a surprise that no advocate has yet emerged from the ranks of retired secretaries of state to work to overturn U.S. cultural isolationism. 
